\title{
Combining disease resistance and postharvest quality traits by early marker-assisted
}

\section{backcrossing in carioca beans}

\author{
Jean Fausto de Carvalho Paulino ${ }^{1 *} \odot$, Caléo Panhoca de Almeida ${ }^{1} \odot$, Isabella Laporte Santos ${ }^{1 \oplus}$, João Guilherme Ribeiro Gonçalves ${ }^{2} \odot$, \\ Sérgio Augusto Morais Carbonel12๑, Alisson Fernando Chiorato ${ }^{2}{ }^{\oplus}$, Luciana Lasry Benchimol-Reis ${ }^{1 \odot}$
}

IInstituto Agronômico/Centro de Recursos Genéticos Vegetais, Av. Dr. Theodureto de Almeida Camargo, 1500 13075-630 - Campinas, SP - Brasil.

Instituto Agronômico/Centro de Grãos e Fibras, Av. Dr. Theodureto de Almeida Camargo, 1500 - 13075-630 Campinas, SP - Brasil.

*Corresponding author <jeanbiotec@gmail.com>

Edited by: Leonardo Oliveira Medici

Received August 04, 2020

Accepted December 04, 2020
ABSTRACT: Common bean is a worldwide important crop. The development of varieties with durable resistance to diseases is a major challenge in common bean breeding. The present study aimed at evaluating the phenotypic and molecular selection of anthracnose resistance in a population obtained by assisted backcrossing from IAC Formoso (resistant, donor parent) $\times$ BRS Pérola (susceptible, recurrent parent). Nine microsatellites (SSRs) and one Sequence Tagged Sites (STS) markers previously linked to ANT resistance were used to genotype this progeny, and the results showed that the selection of the genotypes closest to the donor parent in the $\mathrm{BC}_{1} \mathrm{~F}_{1}$ population decreased the number of backcrossing cycles necessary to obtain advanced isogenic lines, potentiating the use of this tool for early selection of resistant cultivars. A total of $31 \%$ of the $\mathrm{BC}_{1} \mathrm{~F}_{1}$ progeny was selected and backcrossed again. The progeny derived from the second backcross $\left(\mathrm{BC}_{2} \mathrm{~F}_{3}\right)$ was selected for the Carioca grain ideotype, and $42 \%$ of the genotypes showed high resistance to anthracnose under controlled conditions of infection for races 65 and 81 . Superior resistant plants were selected and evaluated under natural conditions of infection to fusarium wilt and angular leaf spot, allowing the selection of two inbred lines with higher resistance to anthracnose, fusarium wilt, angular leaf spot and postharvest quality traits such as yield, 100 seed weight, $L$ value at seed harvest grain darkening and cooking time. The approach outlined in this paper proved to be effective to simultaneously select for disease resistance without losing technological quality aspects of the bean.

Keywords: Phaseolus vulgaris, SSRs, marker-assisted selection, genetic resistance, grain darkening

\section{Introduction}

Common bean / dry edible bean (Phaseolus vulgaris L.), together with rice, constitutes a staple food of the Brazilian population, with nutritional and economic importance. It is the most consumed species of the Phaseolus genus (Broughton et al., 2003; CONAB, 2019). One of the factors that affect yield in Brazil is the prevalence of bean plant diseases, with more than 45 types. Some of the most widespread diseases that cause extensive damage are the fungal ones that affect the aerial part, such as anthracnose (ANT), angular leaf spot (ALS), and rust (Silva et al., 2007). Another important disease is the fusarium wilt, which is a soil and seed borne disease caused by Fusarium oxysporum Schlecht. f. sp. phaseoli Kendrick \& Snyder (Fop, Pereira et al., 2013).

The anthracnose caused by Colletotrichum lindemuthianum (Sacc. and Magnus) Briosi and Cavara. is one of the most destructive diseases as it occurs in the three growing seasons (rainy, dry and winter) with reduction in the production and quality of the grain produced (Chiorato et al., 2006). The pathogen is characterized by its wide variability, with more than 182 physiological races identified worldwide (Padder et al., 2017). Anthracnose resistance in common bean is governed by monogenic independent genes identified by the Co symbol (Ferreira et al., 2013). Nowadays, there have been found around 25 major ANT resistance genes belonging to the Andean and Mesoamerican gene pools (Banoo et al., 2020; Vaz Bisneta and Gonçalves-Vidigal, 2020).

However, a strategy for accelerating plant breeding is to introgress quantitative trait loci (QTLs) through marker-assisted backcrossing (MABC), and then, perform a final phenotypic screen to select the best varieties (Ribaut et al., 2010). Previous studies used MABC to develop common bean cultivars with resistance to multiple biotic stress (Alzate-Marin et al., 1999; Boersma et al., 2014; Kelly and Vallejo, 2004; Miklas et al., 2006; Oliveira et al., 2008; Tryphone et al., 2013).

The MABC method has been the most effective strategy employed in common beans to obtain beneficial QTLs from donor parents with shortened time frame in both foreground and background selection (Carneiro et al., 2010; Kelly, 2004; Varshney et al., 2010). Indeed, QTL detection is facilitate in the backcrossed inbred lines (Kaeppler, 1997) as these loci have a greater probability of being identical by descent, and their interaction with other traits is more sharply detected (Teran et al., 2020). The purpose of this study was to evaluate a bean marker-assisted backcrossing scheme with the emphasis on obtaining advanced inbred carioca lines resistant to ANT, ALS and Fop diseases and portraying technological quality traits through an early generation MABC approach. 


\section{Materials and Methods}

\section{Plant material and breeding approach}

In order to obtain a plant resistant to ANT, the cultivar IAC Formoso (donor parent) was crossed with the cultivar BRS Pérola (recurrent parent). The IAC Formoso parent originated from the Gen 96A28P4-1-11-1 $\times$ CNFC9484 cross, within the Mesoamerican gene pool. One of its important agronomic characteristics is resistance to some bean diseases, such as anthracnose caused by Colletotrichum lindemuthianum (Carbonell et al., 2010a). The BRS Pérola cultivar resulted from a pure-line selection in the Aporé cultivar (Carioca / México 168 // Carioca / BAT 76). It has a light beige seed coat with light streaks and high yield potential. However, it is susceptible to diseases such as ANT (Melo et al., 2017).

The crosses were carried out in a greenhouse in the early morning due to milder temperatures and higher relative humidity. IAC Formoso was used as a female parent and BRS Pérola as a male parent, and the hybridization procedure began when the plants of IAC Formoso and BRS Pérola entered the R5 (appearance of flower buds) and R6 (opening of the first flower) reproductive phases, respectively.

The $\mathrm{F}_{1}$ seeds obtained from crossing IAC

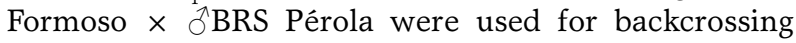
with the recurrent parent BRS Pérola in the manner previously described. The progenies obtained from the first backcross $\left(\mathrm{BC}_{1} \mathrm{~F}_{1}\right)$ were evaluated for the presence of resistance alleles of the donor parent. The genotypes selected were backcrossed again, giving rise to the $\mathrm{BC}_{2} \mathrm{~F}_{1}$ progeny, which was self-pollinated. To meet the commercial requirements of the Brazilian market for the carioca commercial grain type, the $\mathrm{BC}_{2} \mathrm{~F}_{2}$ progenies were selected for absence of yellow hilum, standard carioca color (cream-colored seed coat with brown streaks), sieve size 12, and short oblong/reniform grain shape (Silva et al., 2016). The selected families were multiplied in the field, giving rise to the $\mathrm{BC}_{2} \mathrm{~F}_{3}$ progeny, which was evaluated for resistance to ANT the V3 phenological stage, under controlled environmental conditions greenhouse.

The resistant genotypes were sown in an experimental field for evaluation of resistance to infection from $P$. griseola under natural conditions and for visual selection regarding the appearance of each $\mathrm{BC}_{2} \mathrm{~F}_{3}$ line. Four resistant plants were selected within each family for evaluation the V3 stage in the field, considering plants with desirable seed size and growth habit determined. Seeds from selected plants were sown once more in a field infested with Fusarium oxysporum f. sp. phaseoli, the causal agent of Fusarium wilt. After harvest, the selected $\mathrm{BC}_{2} \mathrm{~F}_{3}$ constituted 5 inbred lines, and they participated in a competitive trial along with commercial controls and the recurrent parent (Figure 1).

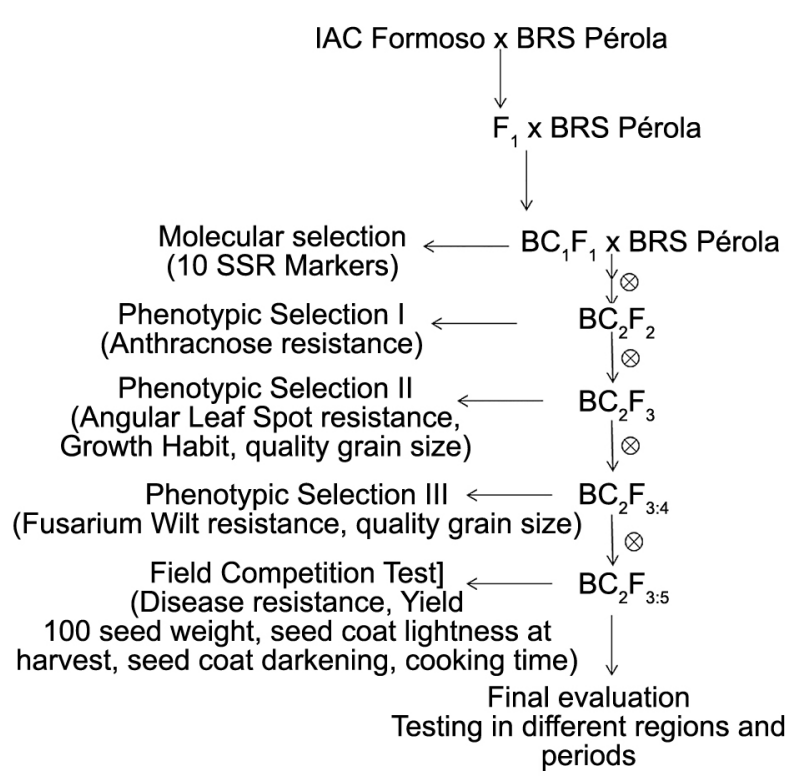

Figure 1 - Schematic representation of the stages of markerassisted backcrossing selection aiming at anthracnose resistance and other important agronomic traits such as resistance to fusarium wilt and angular leaf spot, yield, 100 seed weight, value at seed harvest $(\mathrm{L})$, grain darkening and cooking time.

\section{DNA extraction, genotyping, and marker-assisted selection}

For the modified MABC approach, the first three-leaflet leaf of each $\mathrm{BC}_{1} \mathrm{~F}_{1}$ plant was collected, frozen in liquid nitrogen, macerated, and used for extraction of total DNA. Approximately $50 \mathrm{mg}$ of macerated leaves were used for CTAB extraction according to the protocol proposed by CIMMYT (2005). After extraction, DNA

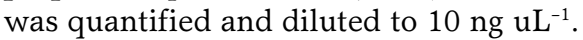

A total of 10 microsatellites (Single Sequence Repeats, SSRs) previously associated with ANT resistance QTL were used for selection of the $\mathrm{BC}_{1} \mathrm{~F}_{1}$ progeny. These markers were characterized for polymorphism between the parents (Table 1). The selected SSRs and STS were associated with 6 ANT resistance QTL (Oblessuc et al., 2014). The g2303 marker was previously associated with the Co-10 (renamed $\mathrm{Co}-3^{4}$ ) and Phg-ON (renamed Phg-3) genes of the Ouro Negro cultivar (Gonçalves-Vidigal et al., 2013).

PCR amplifications were performed in a BioRad thermocycler (My Cycler) with a final volume of 15 $\mu \mathrm{L}[2 \mu \mathrm{L}$ of primer - forward and reverse, $2.5 \mu \mathrm{L}$ of Milli-Q water, $3 \mu \mathrm{L}$ of diluted DNA (30 ng), $7.5 \mu \mathrm{L}$ of Master Mix]. Reaction conditions were the same as described in the previous articles (Campos et al., 2011; Gaitán-Solís et al., 2002; Hanai et al., 2007; McConnell et al., 2010; Oblessuc et al., 2014). The quality of the amplifications was confirmed on a $3 \%$ agarose gel. The amplification products were separated by capillary electrophoresis using a 96-capillary 
Table 1 - Microsatellite (SSR) and Sequence Tagged Site (STS) molecular markers associated with anthracnose resistance loci in previous studies (Gonçalves-Vidigal et al., 2013; Oblessuc et al., 2014).

\begin{tabular}{|c|c|c|c|c|}
\hline Marker & Type & $\begin{array}{c}\text { Linkage } \\
\text { Group }\end{array}$ & QTLs & Reference \\
\hline BMd7 & SSR & 2 & ANT2.2UC & Oblessuc et al. (2014) \\
\hline DROUG & SSR & 2 & ANT2.2 $2^{\mathrm{UC}}$ & Oblessuc et al. (2014) \\
\hline SSR-IAC245 & SSR & 4 & ANT4.1 UC & Oblessuc et al. (2014) \\
\hline g2303 & STS & 4 & Co-34/Phg-3 & $\begin{array}{l}\text { Gonçalves-Vidigal et al. } \\
\text { (2013) }\end{array}$ \\
\hline PVM40 & SSR & 7 & ANT7. $1^{\text {UC }}$ & Oblessuc et al. (2014) \\
\hline $\begin{array}{l}\text { BM210 } \\
\text { BM185 } \\
\text { SSR-IAC262 }\end{array}$ & $\begin{array}{l}\text { SSR } \\
\text { SSR } \\
\text { SSR }\end{array}$ & $\begin{array}{l}7 \\
7 \\
7\end{array}$ & $\begin{array}{l}\text { ANT7.3 } \\
\text { ANT7. } 3 \text { Uc } \\
\text { ANT7.3 }\end{array}$ & $\begin{array}{l}\text { Oblessuc et al. (2014) } \\
\text { Oblessuc et al. (2014) } \\
\text { Oblessuc et al. (2014) }\end{array}$ \\
\hline BM165 & SSR & 8 & ANT8.1 UC & Oblessuc et al. (2014) \\
\hline SSR-IAC143 & SSR & 11 & ANT11.1 Uc & Oblessuc et al. (2014) \\
\hline
\end{tabular}

Automated CE System, using the DNF-905 doublestranded DNA Reagent Kit. For this analysis, $5 \mu \mathrm{L}$ of each amplification product was diluted in $19 \mu \mathrm{L}$ of buffer and placed in 96-well microplates.

The genotype matrix was converted into a numerical GenAlEx format in which the allele of each genotype was compared to parental alleles, with the allele of the resistant parent (IAC Formoso) represented by the number 1 and the susceptible parent (BRS Pérola) by the number 2. As the species is diploid, the allele numbers were considered twice, both for homozygous (11 or 22) and for heterozygous (12). First, the genetic distance of Nei (1978) was estimated by the POPPR package (Kamvar et al., 2015), and then, the genotypes were clustered by neighborjoining analysis. Principal Component Analysis (PCA) was also performed by the ADE 4 package (Dray et al., 2007), and were used to better explore the variability of the inbred lines using a multivariate analysis approach. The genes from the donor parent in the $\mathrm{BC}_{1} \mathrm{~F}_{1}$ progeny for the resistance loci under evaluation was determined by the total number of alleles of the IAC Formoso parent identified in each one, including SSRs and STS in homozygosity and heterozygosity.

The last step consisted of selection of the genotypes to be backcrossed, which were discriminated and grouped by Discriminant Analysis of Principal Components (DAPC) proposed by Jombart et al. (2010) and implemented in the ADEGENET v2.1.1 package (Jombart et al., 2011), which is considered free of Hardy-Weinberg and linkage equilibrium. DAPC analysis consists of the transformation of genotypic data by the PCA into components that better explain the genetic variance, and they are used for linear Discriminant Analysis (DA). Therefore, the genetic variance within the group is minimized and between groups is maximized (Jombart et al., 2010). The number of groups required for clustering was two, one group for the resistant parent and another for the susceptible parent. Due to the high heterosis expected for the $\mathrm{BC}_{1} \mathrm{~F}_{1}$ generation and the recovery of the recurrent parental genome, all genotypes with a participation coefficient greater than $10 \%$ for the resistant group were selected.

\section{Evaluation and selection for anthracnose resistance}

After the prior molecular selection with microsatellites based on the donor parent, the second backcross was performed, followed by self-pollination to obtain a larger number of individuals in the population aiming at gain from selection. Thus, $\mathrm{BC}_{2} \mathrm{~F}_{2}$ genotypes were obtained, which were evaluated for the severity of resistance to ANT in an experiment with artificial inoculation, with IAC Formoso and BRS Pérola as resistant and susceptible controls, respectively.

A randomized block experimental design (RBD) was used, with three replications. Each block was composed of two plots of the same genotype, each plot consisting of a pot with two plants. Twenty seeds of each genotype were pre-germinated on germination paper (Germitest), previously moistened with distilled water, and placed in a BOD incubator for germination at $24^{\circ} \mathrm{C}$ for three days. Subsequently, under greenhouse conditions, the seeds with radicle emergence were transplanted in plastic pots (11 $\times 8 \times 9 \mathrm{~cm})$ containing plant substrate, and they were irrigated once a day. When $50 \%$ of the plants showed complete expansion of the first three-leaflet leaf, marking the beginning of the V3 phenological stage, they were placed in an inoculation chamber, where they remained under controlled temperature $\left(21^{\circ} \mathrm{C}\right)$, humidity (95-100 \%) and photoperiod (12/12) conditions, ideal for development of the pathogen (Pastor-Corrales et al., 1995).

For inoculation, the monosporic isolate previously characterized as physiological race 65 was used, and to obtain conidia for inoculation, the fungus was cultivated in tubes with pods to stimulate sporulation of the colonies and obtain more conidia at a concentration of $1.2 \times 10^{6}$ conidia $\mathrm{mL}^{-1}$ for inoculation (Pastor-Corrales et al., 1995).

Plants were inoculated by manual spraying with an air compressor (De Vilbiss) on both the adaxial and abaxial surfaces of each plant. Evaluation of disease severity occurred 10 days after inoculation and was performed using a scoring scale from 1 to 9 , where 1 represents no visible symptoms (i.e., immune) and 9 represents severely diseased (Pastor-Corrales et al.,1995).

The final score for each genotype was comprised by the arithmetic mean of the individual evaluation in each block; heritability in the broad sense and the analysis of variance were performed by the RBio program (Bhering, 2017). 
Field evaluation and selection for angular leaf spot resistance and agronomic traits of interest

The genotypes considered to be resistant to anthracnose (score < 3) constituted the $\mathrm{BC}_{2} \mathrm{~F}_{3}$ progeny, which were sown in a field infested with the $P$. griseola pathogen that causes angular leaf spot, to assess resistance under natural conditions of infection. A randomized block design was used with 4 replications. The plot consisted of 10 plants sown in a $1-\mathrm{m}$ row, with $0.5 \mathrm{~m}$ spacing between rows. The AND 277 and IAC Milênio cultivars were included as resistant and susceptible controls, respectively, between treatments. To increase the degree of infection in the experiment, artificial inoculation was performed using a mixture of $P$. griseola isolates at a concentration of $2 \times 10^{4}$ conidia $\mathrm{mL}^{-1}, 30$ days after sowing (Van-Schoonhoven and Pastor-Corrales, 1987), where plants with infection scores from 1 to 3 were considered resistant, from 4 to 6 moderately resistant, and from 7 to 9 susceptible. The final score of each genotype was comprised by the arithmetic mean of the 6 plants evaluated in each plot.

Individual plants were selected among the plots considered as resistant based on agronomic performance, considering determined (type I) growth habit, number of pods, pod size, first pod height, stem diameter, and resistance to other diseases, constituting the $\mathrm{BC}_{2} \mathrm{~F}_{3: 4}$.

\section{Field evaluation and selection for resistance to Fusarium wilt}

The selected lines of the $\mathrm{BC}_{2} \mathrm{~F}_{3}{ }_{4}$ progeny was planted in the field with natural infestation of Fusarium oxysporum f. sp. phaseoli (Fop) causing Fusarium wilt, the field evaluation was conducted in an area with a history of occurrence of Fusarium wilt that is routinely used to test genotypes for the reaction to Fop. It was used disease severity rating with a scoring scale adapted from Pastor Corrales and Abawi (1987), ranging from 1 to 9: 1 = no symptoms; 3 = light vascular discoloration on one side of the stem and symptoms of chlorosis, wilt and necrosis restricted to the first leaves of the plant; 5 = traces of intermediate vascular discoloration throughout the length of the stem and symptoms of chlorosis, wilt and necrosis in the leaves below the pointer; $7=$ dark vascular discoloration throughout the length of the stem and severe symptoms of wilt and necrosis generalized in the aerial part and $9=$ dead plant. The plants with scores 1.0 to 3.0 were classified as resistant; from 3.1 to 6.0 as intermediate and from 6.1 to 9.0 as susceptible (Pastor Corrales and Abawi, 1987).

After harvest, the selected $\mathrm{BC}_{2} \mathrm{~F}_{3: 5}$ lines were included in a competitive trial between commercial and parental controls to assess the success of backcrosses in obtaining lines superior to the recurrent parent, as well as to compare agronomic performance in relation to other commercial cultivars.

\section{Competitive trials, grain quality traits, and anthracnose resistance}

The experiment was carried out during the dry season in Campinas, São Paulo, Brazil (22 $54^{\prime}$ S, 47 $03^{\prime}$ W, altitude of $854 \mathrm{~m}$ ) in 2019. A randomized block design was adopted, with 3 replications. Each plot was composed of $4 \mathrm{~m}$ rows, with 10 plants in each row. In addition to the selected lines, the IAC Formoso and BRS Pérola cultivars were sown as control cultivars. The crop treatments were in conformity with bean's requirements; however, fungicide and acaricide were not used.

The length of the cycle, plant size, plot appearance, and disease incidence were evaluated during the experiment. At harvest, only the central rows of each plot were considered, with evaluation of the following traits: yield $\left(\mathrm{kg} \mathrm{ha}^{-1}\right), 100$ seed weight (g), L value at seed harvest, grain darkening, cooking time, and anthracnose resistance.

The cooking analysis was performed following the methodology proposed by Proctor and Watts (1987), with adaptations. Approximately $30 \mathrm{~g}$ of whole uniform seeds were sampled, which were soaked in distilled water for $16 \mathrm{~h}$, at room temperature. Of these, 25 beans were chosen at random and placed in the Mattson Cooker.

The assessment of lightness (L) of the seed coat was performed with a chroma meter (model CR-10). One hundred beans from each plot were randomly sampled and used to read L after harvest. They were then stored in transparent plastic bags and left on shelves under natural light (fluorescent) for 12-h photoperiod. The positions of the seeds were changed weekly through side inversion, aiming at complete exposure of the grain to light, and the plastic bags were randomized again under the shelf. The second luminosity reading was performed after 30 days of storage.

Finally, as all cultivars recommended by the bean breeding program of the Agronomic Institute (IAC) must be resistant to ANT, the resistance of the selected lines was confirmed by inoculation with a mixture of the Colletotrichum lindemuthianum isolates, corresponding to physiological races 65 and 81 . Survey studies in Brazilian bean producing regions have been carried out and races $65,73,81$ and 89 have been the most frequent (Ferreira et al., 2008; Mahuku and Riascos, 2004; Pinto et al., 2012; Ribeiro et al., 2016; Silva et al., 2007). Among these, race 65, has been reported as a stable race and widely distributed in most producing regions. Inoculation and evaluation followed the same steps described above in 2.3 .

\section{Results}

\section{Marker-assisted selection}

The relationship between the remaining 29 genotypes and the parental distance can be visualized through the PCA scatter plot and the dendrogram (Figure 2). 


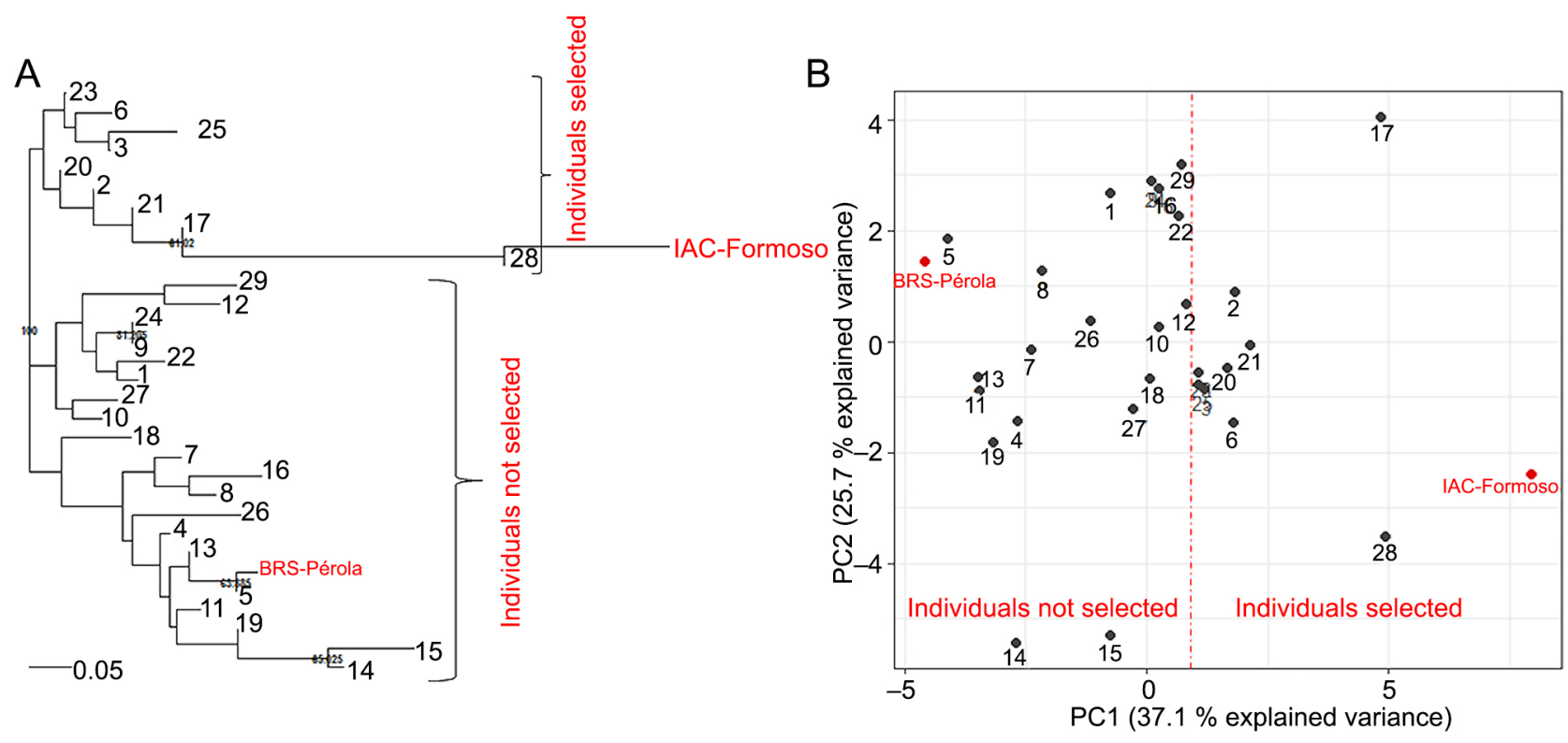

Figure 2 - Neighbor-joining dendrogram from Nei's (1978) genetic distance estimates (A), and Principal Component Analysis (PCA) (B) calculated for the $\mathrm{BC}_{1} \mathrm{~F}_{1}$ progeny and the parents from 10 molecular markers. Nine individuals were selected based on the donor parent alleles (inside the red outline: $2,3,6,17,20,21,23,25$, and 28 ).

The average heterosis observed was $47 \%$ for the $\mathrm{BC}_{1} \mathrm{~F}_{1}$ lines for the 9 SSRs and 1 STS, with genotypes 3, 20, 21 , and 23 being the most heterozygous (> $75 \%$ ). The average percentage of genome introgression from the donor parent for the ANT resistance loci was $33.5 \%$, indicating success in the crosses.

The PCA clearly separated the parents in the $1^{\text {st }}$ component, which explained $34.1 \%$ of the genetic variance, while $25.7 \%$ of the variance was explained by $2^{\text {nd }}$ component. As expected, the progeny was clustered closer to the recurrent parent since it represented $66.8 \%$ of the progeny's genetic base.

The clustering carried out by DAPC and plotted in two distinct groups was used for molecular selection. The donor (resistant) parent was located in group 2, with $100 \%$ of the participation coefficient, whereas the recurrent (susceptible) parent was located in group 1. Nine genotypes $(2,3,6,17,20,21,23,25$, and 28), with a participation coefficient greater than $90 \%$ for the resistant parent group, were selected for the second backcross cycle (Figure 3).

However, in the present study, genotypes clustered with the recurrent parent were discarded according to the analyses observed in the PCA and DAPC dendrogram, since the markers used were associated with ANT resistance loci and, the objective was the selection of genotypes with alleles of the resistant parent (IAC Formoso).

\section{Phenotypical selection $\left(\mathrm{BC}_{2} \mathrm{~F}_{2}\right.$ and $\left.\mathrm{BC}_{2} \mathrm{~F}_{3: 4}\right)$}

The 9 genotypes selected were backcrossed with the recurrent parent (BRS Pérola), with an average of 3 crosses per plant and 3 seeds per pod, for a total of 81 $\mathrm{BC}_{2} \mathrm{~F}_{1}$ plants. Each seed obtained was planted under greenhouse conditions in an individual pot and was harvested separately. Backcrossing was an advantage, as $31 \mathrm{BC}_{2} \mathrm{~F}_{2}$ genotypes were selected in all and gain was observed for grain size and quality in relation to the recurrent parent.

For the $31 \mathrm{BC}_{2} \mathrm{~F}_{2}$ genotypes evaluated for $\mathrm{ANT}$ resistance under controlled conditions with inoculation, 13 plants $(41.9 \%)$ showed resistance to race 65 (score $<3$ ). The average scores of the IAC Formoso and BRS Pérola parents were 1.3 and 7.5, respectively. Analysis of variance (ANOVA) confirmed the variability between genotypes due to the high significance of the $\mathrm{F}$ test $(p<$ $0.0001)$, however, broad sense heritability was moderate $\left(\mathrm{h}^{2}=0.77\right)$.

The incidence of the disease was confirmed by the disease symptoms in the susceptible control IAC Milênio, which had an average score of 6.8. All the 9 $\mathrm{BC}_{2} \mathrm{~F}_{3}$ genotypes $(25.7 \%$ ) showed resistance (score < 4). Analysis of variance revealed significance for genotypes, and heritability was 0.70 .

The $\mathrm{BC}_{2} \mathrm{~F}_{3}$ genotypes considered as resistant plants were selected based on their agronomic appearance, such as determined growth habit, larger number of pods, greater first pod height, larger stem diameter, and early maturity. In all, 6 selected plants were harvested individually and sown in the field with natural infestation of Fusarium oxysporum f. sp. phaseoli $(F o p)$, causing Fusarium wilt, for seed multiplication of $\mathrm{BC}_{2} \mathrm{~F}_{3: 4}$. During multiplication and evaluation, two 

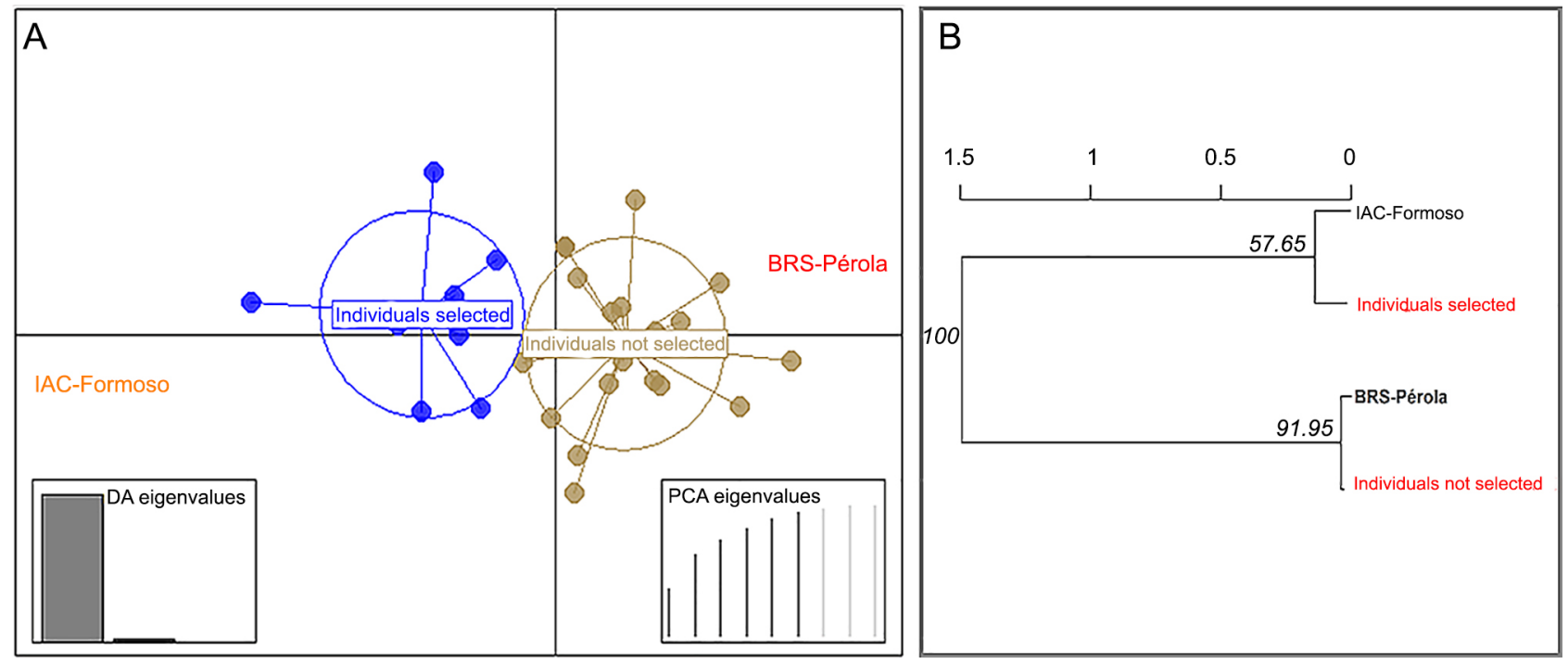

Figure 3 - Discriminant Analysis of Principal Components (DAPC) with $\mathrm{K}=2$ : (A) From parental clustering, the group on the left in blue indicates the respective genotypes ( 9 individuals selected based on the donor parent IAC Formoso). (B) Clustering of parents and the selected and nonselected genotypes based on the neighbor-joining dendrogram.

lines (FP15 and FP75) showed superior appearance and superior resistance to Fop, so they were selected for the competitive trial.

\section{Competitive trial}

The FP15 and FP75 lines of the $\mathrm{BC}_{2} \mathrm{~F}_{3: 5}$ generation were evaluated in a competitive trial with the respective parents, BRS Pérola and IAC Formoso, as control cultivars. The selected lines performed better than IAC Formoso and BRS Pérola for almost all the traits evaluated. According to the Tukey test, there was no significant difference in cooking time among the four genotypes. Regarding 100 seed weight, both lines had a significantly higher weight than BRS Pérola, especially FP75, which had $25 \%$ greater yield in relation to the recurrent parent and $16 \%$ in relation to the donor parent. There was no significant difference for lightness $(\mathrm{L}=0)$ at harvest between the lines, IAC Formoso and BRS Pérola (control cultivars). In analysis of darkening due to loss of lightness, the FP75 line also showed less loss of (L) and, consequently, lighter colored grain. It did not differ significantly from IAC Formoso and the FP15 line, but it remained lighter than BRS Pérola after 30 days on the shelf (Table 2).

\section{Discussion}

\section{Marker-assisted selection and Phenotypical selection $\left(\mathrm{BC}_{2} \mathrm{~F}_{2}\right.$ and $\left.\mathrm{BC}_{2} \mathrm{~F}_{3: 4}\right)$}

Higher than expected parent introgression values were also reported by Oliveira et al. (2008), with average introgression of $29.6 \%$ and $32.8 \%$ for two
Table 2 - Yield $\left(\mathrm{kg} \mathrm{ha}^{-1}\right), 100$ seed weight $(\mathrm{g}), \mathrm{L}$ value at seed harvest, grain darkening, cooking time, and anthracnose resistance, coefficient of experimental variation (CV\%) and Tukey test per sowing in the dry season in comparison with IAC Formoso and BRS Pérola as control cultivars in the competitive trials of common beans (Campinas, São Paulo, Brazil), in 2019.

\begin{tabular}{|c|c|c|c|c|c|c|}
\hline \multirow{2}{*}{$\begin{array}{l}\text { Carioca } \\
\text { bean cultivar }\end{array}$} & \multicolumn{6}{|c|}{ Agronomic trait } \\
\hline & Yield & $\begin{array}{c}100 \text { seed } \\
\text { weight }\end{array}$ & L & Darkening & Cooking & ANT \\
\hline & $\mathrm{kg} \mathrm{ha}^{-1}$ & g & & $\Delta \mathrm{L}$ & $\min$ & \\
\hline IAC Formoso & $2.408 a b^{*}$ & $32.2 \mathrm{a}$ & $55.0 \mathrm{a}$ & $3.0 \mathrm{ab}$ & $18.0 \mathrm{a}$ & $1 \mathrm{a}$ \\
\hline BRS Pérola & $2.243 b$ & $29 b$ & $55.9 a$ & $3.8 \mathrm{a}$ & $19.6 \mathrm{a}$ & $8 b$ \\
\hline FP15 & $2.174 b$ & $27.3 c$ & $54.8 \mathrm{a}$ & $2.8 \mathrm{ab}$ & $22.3 a$ & $1 \mathrm{a}$ \\
\hline FP75 & $2.814 \mathrm{a}$ & $26.5 \mathrm{c}$ & $54.7 \mathrm{a}$ & $2.62 \mathrm{~b}$ & $20.0 \mathrm{a}$ & $1 \mathrm{a}$ \\
\hline Mean & 2.409 & 28.7 & 55.1 & 3.1 & 20 & 2.75 \\
\hline CV\% & $9.3 \%$ & $2.0 \%$ & $0.9 \%$ & $12.3 \%$ & $11.4 \%$ & $5.4 \%$ \\
\hline
\end{tabular}

ANT $=$ Anthracnose resistance races 65 and $81 ; \mathrm{CV} \%=$ Coefficient of experimental variation; * The different letters represent the groupings by the Tukey test.

$\mathrm{BC}_{1} \mathrm{~F}_{2}$ common bean progenies evaluated by 20 SSRs. Some of the possible causes for higher than expected introgression values are the low number of markers used, the lack of coverage of all chromosomes, and the association of some markers with the same genomic region, as they were previously associated with ANT resistance QTL and the Co-10 (renamed $\mathrm{Co}-3^{4}$ ) and $\mathrm{Phg}$ ON (renamed Phg-3) genes of the Ouro Negro and IAC UNA cultivars cultivar (Gonçalves-Vidigal et al., 2013; Oblessuc et al., 2014; Table 1).

Most of ANT genes show complete dominance (Ferreira et al., 2013), except for the recessive gene co-8 (Alzate-Marin et al., 1997). From the major genes and 
respective alleles identified until now, 17 were numbered from $\mathrm{Co}_{-} 1$ to $\mathrm{Co}-17$, and others received alphabet letters such as Co-u, Co-v, Co-w, Co-x, Co-y, Co-z, Co-AC, Co$\mathrm{Pa}, \mathrm{Co}-1^{H Y}, \mathrm{CoPv01}{ }^{\mathrm{CDRK}}$ and Co-RVI (Banoo et al., 2020; Vaz Bisneta and Gonçalves-Vidigal, 2020; Zuiderveen et al., 2016). Some resistance genes were named after their chromosome location, name of the isolate or race (in superscript), followed by the bean genotype in which the resistance gene was identified such as $C O P v 02 c^{3-X}$, CoPv02c c-X, CoPv02c ${ }^{19-X}, C o P v 02 c^{449-X}$ and CoPv09c $c^{453-C}$ (Campa et al., 2014). Most classical studies considered that different resistance spectra in genotypes were due to different alleles of the same gene.

Quantitative resistance loci (QRLs) has also been reported and genomic regions associated with important races such as the $3,4,9,38,55,65,73,87$, 503, 2047 and 3481 (Banoo et al., 2020; Oblessuc et al., 2014; Perseguini et al., 2016; Vidigal-Filho et al., 2020). Indeed, these Co loci may be part of disease resistance clusters and QRL on all bean chromosomes (from Pv01 to Pv11, Banoo et al., 2020; Campa et al., 2014; Ferreira et al., 2013; Geffroy et al., 2008; Gonçalves-Vidigal et al., 2011; Gonçalves-Vidigal et al., 2012; Gonçalves-Vidigal et al., 2013; Mungalu et al., 2020; Murube et al., 2019; Oblessuc et al., 2014; Perseguini et al., 2016; Richard et al., 2014; RodríguezSuárez et al., 2007; Sousa et al., 2014; Vaz Bisneta and Gonçalves-Vidigal, 2020; Vidigal-Filho et al., 2020; Zuiderveen et al., 2016).

Additional analyses have revealed that some of these loci are organized in closely linked race-specific gene clusters, which is especially evident on Pv01, Pv02, Pv04, Pv07, Pv08 and Pv11 (Campa et al., 2009, 2014; Chen et al., 2017; Davide and Souza, 2009; GonçalvesVidigal et al., 2011, 2012, 2013; Meziadi et al., 2016; Oblessuc et al., 2014; Rodríguez-Suárez et al., 2007; Zuiderveen et al., 2016). Disease resistance genes and QTL are clustered in the genome, and the immune response can be demonstrated in genetic and associative mapping (Neupane et al., 2018; Perseguini et al., 2016; Valentini et al., 2017; Vidigal-Filho et al., 2020).

In this study, 35 selected genotypes were used for an experiment to evaluate resistance under natural conditions of $P$. griseola in the field. Fritsche-Neto et al. (2019) reported an estimated heritability of 0.64 for anthracnose under field conditions and SNPs associated to ANT on Pv02 and heritability of 0.93 and SNPs associated for ALS on Pv10. Pereira et al. (2019) demonstrated an observed heritability of 0.79 under conditions of natural incidence of angular leaf spot.

Apart from being resistant to ANT, the IAC Formoso was resistant to angular leaf spot and fusarium wilt. According to Gonçalves-Vidigal et al. (2011), there may be co-segregation of genes from more than one disease, as in the case of the Phg-1 gene, which is strongly linked to the $\mathrm{Co}^{-1}{ }^{4}$ gene present in the AND 277 cultivar, responsible for providing resistance to ANT race 65 .
Previous studies with the Ouro Negro cultivar by Gonçalves-Vidigal et al. (2013) revealed that the ANT resistance $\mathrm{Co}-10$ (renamed $\mathrm{Co}-3^{4}$ ) and $\mathrm{Phg}-\mathrm{ON}$ (renamed Phg-3) genes approved by the Genetic Committee BIC co-segregated and were tightly linked at a distance of $0.0 \mathrm{cM}$ on Pv04. The close linkage between the Co- $3^{4}$ and $\mathrm{Phg}-3$ genes and prior evidence are consistent with the existence of a resistance gene cluster in the end of chromosome $\mathrm{Pv} 04$, that besides containing the $\mathrm{Co}^{-} 3^{4}$ and Phg-3 contains the ANT resistance QTL ANT4. $1^{\mathrm{UC}}$ (Oblessuc et al., 2014).

After $\mathrm{BC}_{2} \mathrm{~F}_{2}$ harvest, segregation was observed for grain quality, and all genotypes that did not show the standard commercial Carioca seed tegument ideotype, particularly those with darker colored beans at harvest, were discarded in $\mathrm{BC}_{2} \mathrm{~F}_{3}$ and $\mathrm{BC}_{2} \mathrm{~F}_{4}$. The slow darkening of beans is a trait desired by bean breeders and a strong characteristic of the IAC Formoso parent, as consumers consider that darker beans require a longer time to cook (Carbonell et al., 2010a; Spitti et al., 2019).

\section{Competitive trial}

Regarding the diseases evaluated, both lines selected showed high resistance for anthracnose, angular leaf spot, and fusarium wilt. The cross between the IAC Formoso and BRS Pérola cultivars not only exhibited resistance to angular leaf spot, fusarium wilt but also allowed the introgression of ANT resistance to physiological races 65 and 81 , races of extreme agronomic importance due to their frequent occurrence in Brazil (Ribeiro et al., 2016).

Obtaining lines superior to the parents is a consequence of strategic planning in the formation of blocks of crosses aiming at the choice of parent combinations for the greatest number of favorable characteristics. The IAC Formoso cultivar has grain quality, upright growth habit, semi-early cycle, and ANT resistance, and it is considered tolerant to the golden mosaic virus and Fusarium solani, which are considered important diseases. These are traits of interest for a commercial cultivar (Carbonell et al., 2010a).

The BRS Pérola cultivar, considered for many years as a reference for the commercial carioca grain type, has resistance to the soil pathogen Fusarium oxysporum f. sp. phaseoli, the causal agent of Fusarium wilt, and common mosaic (Melo et al., 2017). It is noteworthy that although the BRS Pérola cultivar has a good sieve yield, with medium-sized grains between sieves 12 and 13 (Carbonell et al., 2010b).

According to Carbonell et al. (2010b), not only yield and grain size determine the success of a bean cultivar, but also other traits inherent to the cultivars. Therefore, besides these prominent traits, a common bean cultivar must have resistance to grain darkening, tolerance to biotic and abiotic factors, upright plant architecture, nutritional and technological quality, and post-harvest quality. The combination of all desirable characteristics in a single genotype is not an easy task, 
since, once one trait of interest is introgressed and fixed, there is the possibility of damaging other traits by linkage drag (Hospital, 2001).

The combination of elite cultivars, as in the case of the cultivars selected as parents in this study with the aid of molecular markers used in early generations of backcrossing proved to be an efficient strategy. The main advantage is that many plants with unwanted gene combinations, especially those that lack essential disease resistance traits and carioca ideotype can be simply discarded associating phenotypical selection in the process. This has important consequences in the later stages of the breeding program because the evaluation for other traits can be more efficiently and cheaply designed for fewer breeding lines, especially in terms of field space. After selection, lines were obtained with superior resistance to the main Brazilian bean diseases (ANT, ALS, Fop) and with postharvest quality traits, such as yield, 100 seed weight, L value at seed harvest, grain darkening and cooking time.

The use of the molecular markers previously described as associated with ANT resistance genes for selection of genotypes with a greater number of resistant parent alleles proved to be an efficient strategy in the selection of the first backcross, using phenotypical selection after the first backcross. Currently, one of the most important barriers for MAS (marker-assisted selection) today is the prohibitive costs. For early generation $\mathrm{MABC}$, the initial cost of using markers would be not very expensive compared to conventional breeding in the short term, and time savings could lead to an accelerated variety release which could translate into greater profits in the medium to long term. Phenotypic selection is not feasible in the first backcross generation, due to the small number of seeds and high rate of heterozygosity. The effectiveness of the scheme resulted in two lines with multiple disease resistance and superiority for several agronomic traits.

\section{Acknowledgments}

The authors thank the São Paulo Research Foundation (FAPESP) for research project grants (2014/11145-2 and 2017/01753-3), and Coordination for the Improvement of Higher Level Personnel (CAPES), for the granting of the scholarships, which enabled this study to be carried out. $1^{\text {st }}$ author thanks CAPES for a doctoral scholarship.

\section{Authors' Contributions}

Conceptualization: Benchimol-Reis, L.L. Data acquisition: Paulino, J.F.C.; Almeida, C.P.; Santos, I.L.; Gonçalves, J.G.R.G.; Chiorato, A.F.; Carbonell, S.A.M.; Benchimol-Reis, L.L. Data analysis: Paulino, J.F.C.; Almeida, C.P. Design of methodology: BenchimolReis, L.L.; Chiorato, A.F. Writing and editing: Paulino, J.F.C.; Almeida, C.P.; Gonçalves, J.G.R.G.; BenchimolReis, L.L.

\section{References}

Alzate-Marin, A.L.; Baia, G.S.; Paula Junior, T.J.; Carvalho, G.A.; Barros, E.G.; Moreira, M.A. 1997. Inheritance of anthracnose resistance in common bean differential cultivar AB 136. Plant Disease 81: 996-998.

Alzate-Marin, A.L.; Menarim, H.; Arruda, M.C.C.; Chagas, J.M.; Barros, E.G.; Moreira, M.A. 1999. Backcross assisted by RAPD markers for the introgression of $C_{0}-4$ and Co- 6 anthracnose resistant genes in common bean cultivars. Bean Improvement Cooperative 42: 15-16.

Banoo, A.; Nabi, A.; Rasool, R.S.; Mahiya-Farooq, S.M.D.; Ahmad, M.; Parvaze, A.S.; Aasiya, N.; Hamidullah I.; Sharma, P.N.; Padder, B.A. 2020. North-western Himalayan common beans: population structure and mapping of quantitative anthracnose resistance through genome wide association study. Frontiers in Plant Science 11: 571618.

Bhering, L.L. 2017. Rbio: a tool for biometric and statistical analysis using the $\mathrm{R}$ platform. Crop Breeding and Applied Biotechnology 17: 187-190.

Boersma, J.G.; Conner, R.L.; Balasubramanian, P.M.; Navabi, A.; Yu, K.; Hou, A. 2014. Combining resistance to common bacterial blight, anthracnose, and bean common mosaic virus into Manitoba-adapted dry bean (Phaseolus vulgaris L.) cultivars. Canadian Journal of Animal Science 94: 405-415.

Broughton, W.J.; Hernández, G.; Blair, M.W.; Beebe, S.E.; Gepts, P.L.; Vanderleyden, J. 2003. Beans (Phaseolus spp.): model food legumes. Plant and Soil 252: 55-128.

Campa, A.; Giraldez, R.; Ferreira, J.J. 2009. Genetic dissection of the resistance to nine anthracnose races in the common bean differential cultivars MDRK and TU. Theoretical and Applied Genetics 119: 1-11.

Campa, A.; Rodríguez-Suárez, C.; Giraldez, R.; Ferreira, J.J. 2014. Genetic analysis of the response to eleven Colletotrichum lindemuthianum races in a RIL population of common bean (Phaseolus vulgaris L.). BMC Plant Biology 14: 115.

Campos, T.; Oblessuc, P.R.; Sforça, D.A.; Cardoso, J.M.K.; Baroni, R.M.; Benchimol, L.L.; Carbonell, S.A.M.; Chioratto, A.F.; Garcia, A.A.F.; Souza, A.P. 2011. Inheritance of growth habit detected by genetic linkage analysis using microsatellites in the common bean (Phaseolus vulgaris L.). Molecular Breeding 27: 549-560.

Carbonell, S.A.M.; Chiorato, A.F.; Carvalho, C.R.L.; Ramos Junior, E.U.; Ito, M.A.; Borges, W.L.B.; Ticelli, M.; Santos, N.C.B.; Boller Gallo, P. 2010a. IAC Formoso: new carioca common bean cultivar. Crop Breeding and Applied Biotechnology 10: 374-376.

Carbonell, S.A.M.; Chiorato, A.F.; Gonçalves, J.G.R.; Perina, E.F.; Carvalho, C.R.L. 2010b. Commercial grain size in common bean. Ciência Rural 40: 2067-2073 (in Portuguese, with abstract in English).

Carneiro, F.F.; Santos, J.B.; Leite, M.E. 2010. Marker-assisted backcrossing using microsatellites and validation of SCAR Phs marker for resistance to white mold in common bean. Electronic Journal of Biotechnology 13: 9-10.

Chen, M.; Wu, J.; Wang, L.; Mantri, N.; Zhang, X.; Zhu, Z. 2017. Mapping and genetic structure analysis of the anthracnose resistance locus $\mathrm{Co}-1^{H Y}$ in the common bean (Phaseolus vulgaris L.). PLoS One 12: e0169954. 
Chiorato, A.F.; Carbonell, S.A.M.; Dias, A.L.A.S.D.; Moura, R.R.; Chiavegato, M.B.; Colombo, C.A. 2006. Identificatiom of common bean (Phaseolus vulgaris) duplicates using agromorphological and molecular data. Genetics and Molecular Biology 29: 105-111.

Companhia Nacional de Abastecimento [CONAB]. 2019. Monitoring of the Brazilian Grain Harvest: 2018/19 Harvest, Twelfth Survey $=$ Acompanhamento da Safra Brasileira De Grãos: Safra 2018/19, Décimo Segundo Levantamento. CONAB, Brasília, DF, Brazil (in Portuguese).

Davide, L.M.C.; Souza, E.A. 2009. Pathogenic variability within race 65 of Colletotrichum lindemuthianum and its implications for common bean breeding. Crop Breeding and Applied Biotechnology 9: 23-30.

Dray, S.; Dufour, A.; Chessel, D. 2007. The ade4 package. II. Twotable and K-table methods. R News 7: 47-52.

Ferreira, J.J.; Campa, A.; Pérez-Veja, E.; Giraldez, R. 2008. Reaction of a bean germplasm collection against five races of Colletotrichum lindemuthianum identified in northern spain and implications for breeding. Plant Disease 92: 705-708.

Ferreira, J.J.; Campa, A.; Kelly, J.D. 2013. Organization of genes conferring resistance to anthracnose in common bean. p. 151182. In: Varshney, R.K.; Tuberosa R., eds. Translational genomic for crop breeding: biotic stress. John Wiley, Chichester, UK.

Fritsche-Neto, R.; Souza, T.L.P.O.; Pereira, H.; Santos, L.C.; Melo, L.C.; Novaes, E. B.; Itaraju Junior, B.; Jannink, J-L. 2019. Association mapping in common bean revealed regions associated with anthracnose and angular leaf spot resistance. Scientia Agricola 76: 321-327.

Gaitán-Solís, E.; Duque, M.C.; Edwards, K.J.; Tohme, J. 2002. Microsatellite in common bean (Phaseolus vulgaris): isolation, characterization, and cross-species amplification in Phaseolus ssp. Crop Science 42: 2128-2136.

Geffroy, V.; Sévignac, M.; Billant, P.; Bron, M.; Langin, T. 2008. Resistance to Colletotrichum lindemutchianum in Phaseolus vulgaris: a case study for mapping two independent genes. Theoretical and Applied Genetics 116: 407-415.

Gonçalves-Vidigal, M.C.; Cruz, A.S.; Garcia, A.; Kami, J.; Vidigal Filho, P.S.; Sousa, L.L.; McClean, P.; Gepts, P.; Pastor-Corrales, M.A. 2011. Linkage mapping of the Phg-1 and Co-1 genes for resistance to angular leaf spot and anthracnose in the common bean cultivar AND 277. Theoretical and Applied Genetics 122: 893-903.

Gonçalves-Vidigal, M.C.; Cruz, A.S.; Vidigal Filho, P.S.; Sousa, L.L.; Lacanallo, G.F.; Gepts, P.; Pastor-Corrales, M.A. 2012. Linkage mapping of the Co-10 and Phg-ON genes for resistance to the anthracnose. Annual Report of the Bean Improvement Cooperative 55: 49-50.

Gonçalves-Vidigal, M.C.; Cruz, A.S.; Lacanallo, G.F.; Vidigal Filho, P.S.; Sousa, L.L.; Pacheco, C.M.; McClean, P.; Gepts, P.; PastorCorrales, M.A. 2013. Co-segregation analysis and mapping of the anthracnose $\mathrm{Co}-10$ and angular leaf spot $\mathrm{Phg}$-ON diseaseresistance genes in the common bean cultivar Ouro Negro. Theoretical and Applied Genetics 126 :2245-55.

Hanai, L.R.; Campos, T.; Camargo, L.E.A.; Benchimol, L.L.; Souza, A.P.; Melotto, M.; Carbonell, S.A.M.; Chioratto, A.F.; Consoli, L.; Formighieri, E.F.; Siqueira, M.; Tsai, S.M.; Vieira, M.L.C. 2007. Development characterization and comparative analysis of polymorphism at common bean SSR loci isolated from genic and genomic sources. Genome 50: 266-277.
Hospital, F. 2001. Size of donor chromosome segments around introgressed loci and reduction of linkage drag in markerassisted backcross programs. Genetics 158: 1363-1379.

International Maize and Wheat Improvement Center [CIMMYT]. 2005. Laboratory Protocols: CIMMYT Applied Molecular Genetics Laboratory. 3ed. CIMMYT, Mexico, DF, Mexico.

Jombart, T.; Devillard, S.; Balloux, F. 2010. Discriminant analysis of principal components: a new method for the analysis of genetically structured populations. BMC Genetics 11: 94.

Jombart, T.; Ahmed, I. 2011. ADEGENET 1.3-1: new tools for the analysis of genome-wide SNP data. Bioinformatics 27: 30703071.

Kamvar, Z.N.; Brooks, J.C.; Grünwald, N.J. 2015. Novel R tools for analysis of genome-wide population genetic data with emphasis on clonality. Frontiers in Genetics 6: 208.

Kaeppler, S.M. 1997. Power analysis for quantitative trait locus mapping in populations derived by multiple backcrosses. Theoretical and Applied Genetics 95: 618-621.

Kelly, J.D. 2004. Advances in common bean improvement: some case histories with broader applications. Acta Horticulturae 637: 99-122.

Kelly, J.D.; Vallejo V.A. 2004. A comprehensive review of the major genes conditioning resistance to anthracnose in common bean. HortScience 39: 1196-1207.

Mahuku, G.S.; Riascos, J.J. 2004. Virulence and molecular diversity within Colletotrichum lindemuthianum isolates from Andean and Mesoamerican bean varieties and regions. European Journal of Plant Pathology 110: 253-263.

McConnell, M.; Mamidi, S.; Lee, R.; Chikara, S.; Rossi, M.; Papa, R.; McClean, P. 2010. Syntenic relationships among legumes revealed using a gene-based genetic linkage map of common bean (Phaseolus vulgaris L.) Theoretical and Applied Genetics 121: 1103-1116.

Melo, L.C.; Pereira, H.S.; Faria, L.C.; Souza, T.L.P.O.; Wendland, A.; Díaz, J.L.C.; Carvalho, H.W.L.; Melo, C.L.P.; Costa, A.F.; Magaldi, M.C.; Souza Costa, J.G. 2017. BRS FC402: highyielding common bean cultivar with carioca grain, resistance to anthracnose and fusarium wilt. Crop Breeding and Applied Biotechnology 17: 67-71.

Meziadi, C.; Richard, M.M.; Derquennes, A.; Thareau, V.; Blanchet, S.; Gratias, A.; Geffroy, V. 2016. Development of molecular markers linked to disease resistance genes in common bean based on whole genome sequence. Plant Science 242: 351- 357.

Miklas, P.N.; Kelly, J.D.; Beebe, S.E.; Blair, W.M. 2006. Common bean breeding for resistance against biotic and abiotic stresses: from classical to MAS breeding. Euphytica 147: 106-131.

Mungalu, H.; Sansala, M.; Hamabwe, S.; Mukuma, C.; Gepts, P.; Kelly, J.D.; Kamfwa, K. 2020. Identification of racespecific quantitative trait loci for resistance to Colletotrichum lindemuthianum in an Andean population of common bean. Crop Science 60: 2843-2856.

Murube, E.; Campa, A.; Ferreira, J.J. 2019. Integrating genetic and physical positions of the anthracnose resistance genes described in bean chromosomes Pv01 and Pv04. PLoS One 14: e0212298.

Nei, M. 1978. Estimation of Average Heterozygosity and Genetic Distance from small Number of Individuals. University of Texas, Houston, TX, USA. 
Neupane, S.; Ma, Q.; Mathew, F.M.; Varenhorst, A.J.; Andersen, E.J.; Nepal, M.P. 2018. Evolutionary divergence of TNL disease-resistant proteins in soybean (Glycine $\max$ ) and common bean (Phaseolus vulgaris). Biochemical Genetics 56: 397-422.

Oblessuc, P.R.; Baroni, R.M.; Pereira, G.S.; Chioratto, A.F.; Carbonell, S.A.M.; Briñez, B.; Silva, L.D.C.; Garcia, A.A.F.; Camargo, L.E.A.; Kelly, J.D.; Benchimol, L.L. 2014. Quantitative analysis of race-specific resistance to Colletotrichum lindemuthianum in common bean. Molecular Breeding 34: 1313-1329.

Oliveira, L.K.; Melo, L.C.; Brondani, C.; Peloso, M.J.D.; Brondani, R.P.V. 2008. Backcross assisted by microsatellite markers in common bean. Genetics and Molecular Research 7: 1000-1010.

Padder, B.A.; Sharma, P.N.; Awale, H.E.; Kelly, J.D. 2017. Colletotrichum lindemuthianum the causal agent of bean anthracnose. Journal of Plant Pathology 99: 317-330.

Pastor-Corrales, M.A.; Abawi, G.S. 1987. Reactions of selected bean germplasms to infection by Fusarium oxysporum f. sp. phaseoli. Plant Disease 71: 990-993.

Pastor-Corrales, M.A.; Otoya, M.M.; Molina, A.; Singh, S.P. 1995. Resistance to Colletotrichum lindemuthianum isolates from middle America and Andean South America in different common bean races. Plant Disease 79: 63-67.

Pereira, A.C.; Cruz, M.F.A.; Paula Júnior, T.J.; Rodrigues, F.A.; Carneiro, J.E.S.; Vieira, R.F.; Carneiro, P.C.S. 2013. Infection process of Fusarium oxysporum f. sp. phaseoli on resistant, intermediate and susceptible bean cultivars. Tropical Plant Pathology 38: 323-328.

Pereira, R.; Abreu, A.F.B.; Nalin, R.S.; Souza, E.A. 2019. Phenotyping for angular leaf spot severity and its implication in breeding common bean for resistance. Scientia Agricola 76: 415-423.

Perseguini, J.M.K.C.; Oblessuc, P.R.; Rosa, J.R.B.F.; Gomes, K.A.; Chiorato, A.F.; Carbonell, S.A.M. 2016. Genome-wide association studies of anthracnose and angular leaf spot resistance in common bean (Phaseolus vulgaris L.). PLoS One 11: e0150506.

Pinto, J.M.A.; Pereira, R.; Mota, S.F.; Ishikawa, F.H.; Souza, E.A. 2012. Investigating phenotypic variability in Colletotrichum lindemuthianum populations. Phytopathology 102: 490-497.

Proctor, J.R.; Watts, B.M. 1987. Development of a modified Mattson Bean Cooker procedure based on sensory panel cookability evaluation. Canadian Institute of Food Science and Technology Journal 20: 9-14.

Ribaut, J.M.; De Vicente, M.C.; Delannay, X. 2010. Molecular breeding in developing countries: challenges and perspectives. Current Opinion in Plant Biology 13: 213-218.

Ribeiro, T.; Esteves, J.A.F.; Silva, D.A.; Gonçalves, J.G.R.; Carbonell, S.A.M.; Chiorato, A.F. 2016. Classification of Colletotrichum lindemuthianum races in differential cultivars of common bean. Acta Scientiarum. Agronomy 38: 179-184.

Richard, M.M.S.; Pflieger, S.; Se'Vignac, M.; Thareau, V.; Blanchet, S.; Li, Y.; Jackson, S.A.; Geffroy, V. 2014. Fine mapping of Co$x$, an anthracnose resistance gene to a highly virulent strain of Colletotrichum lindemuthianum in common bean. Theoretical and Applied Genetics 127: 1653-1666.
Rodríguez-Suárez, C.; Méndez-Vigo, B.; Pañeda, A.; Ferreira, J.J.; Giraldez, R. 2007. A genetic linkage map of Phaseolus vulgaris L. and localization of genes for specific resistance to six races of anthracnose (Colletotrichum lindemuthianum). Theoretical and Applied Genetics 114: 713-722.

Silva, M.B.O.; Carvalho, A.J.; Carneiro, J.E.S.; Aspiazú, I.; Alves, É.A.; David, A.M.S.; Brito, O.G.; Alves, P.F.S. 2016. Technological quality of grains of common beans selected genotypes from the carioca group. Semina: Ciências Agrárias 37: 721-732.

Silva, K.J.D.; Souza, E.A.; Ishikawa, F.H. 2007. Characterization of Colletotrichum lindemuthianum Isolates from the state of Minas Gerais, Brazil. Journal of Phytopathology 155: 241-247.

Sousa, L.L.; Cruz, A.S.; Vidigal Filho, P.S.; Vallejo, V.A.; Kelly, J.D.; Gonçalves-Vidigal, M.C. 2014. Genetic mapping of the resistance allele $C_{0}-5^{2}$ to Colletotrichum lindemuthianum in the common bean MSU 7-1 line. Australian Journal of Crop Science 8: 317-323.

Spitti, A.M.D.S.; Carbonell, S.A.M.; Dias, C.T.S.; Sabino, L.G.; Carvalho, C.R.L.; Chiorato, A.F. 2019. Carioca bean genotypes for tolerance to grain darkening by natural and accelerated methods. Ciência e Agrotecnologia 43: e012519.

Teran, J.C.B.M.Y.; Konzen, E.R.; Palkovic, A.; Tsai, S.M.; Gepts, P. 2020. Exploration of the yield potential of mesoamerican wild common beans from contrasting eco-geographic regions by nested recombinant inbred populations. Frontiers in Plant Science 11: 1-18.

Tryphone, G.M.; Chilagane, L.A.; Protas, D.; Kusolwa, P.M.; Nchimbi-Msolla, S. 2013. Marker assisted selection for common bean diseases improvements in Tanzania: prospects and future needs. p. 121-147. In: Anderson, S.B., ed. Plant breeding from laboratories to fields. IntechOpen, London, UK.

Valentini, G.; Gonçalves-Vidigal, M.C.; Hurtado-Gonzales, O.P.; Castro, S.A.L.; Cregan, P.B.; Song, Q.; Pastor-Corrales, M.A. 2017. High-resolution mapping reveals linkage between genes in common bean cultivar Ouro Negro conferring resistance to the rust, anthracnose, and angular leaf spot diseases. Theoretical and Applied Genetics 130: 1705-1722.

Van-Schoonhoven, A.; Pastor-Corrales, M. 1987. Standard System for the Evaluation of Bean Germplasm. Centro Internacional de Agricultura Tropical, Cali, Colombia.

Varshney, R.K.; Glaszmann, J.C.; Leung, H.R.J. 2010. More genomic resources for less-studied crops. Trends Biotechnology 28: $452-460$.

Vaz Bisneta, M.; Gonçalves-Vidigal, M.C. 2020. Integration of anthracnose resistance loci and RLK and NBS-LRR-encoding genes in the Phaseolus vulgaris L. genome. Crop Science 60: 29012918.

Vidigal-Filho, P.S.; Gonçalves-Vidigal, M.C.; Bisneta, M.V.; Souza, V.B.; Gilio, T.A.; Calvi, A.A.; Lima, L.R.; Pastor-Corrales, M.A.; Melotto, M. 2020. Genome-wide association study of resistance to the anthracnose and angular leaf spot diseases in Brazilian Mesoamerican and Andean common bean cultivars. Crop Science 60: 2931-2950.

Zuiderveen, G.H.; Padder, B.A.; Kamfwa, K.; Song, K.; Kelly, J.D. 2016. Genome-wide association study of anthracnose resistance in Andean beans (Phaseolus vulgaris). PLoS One 11: e0156391. 